\title{
Playing in the Shadow of Event Urbanism: Newcomer Youth, Neighborhood Change, and T02015
}

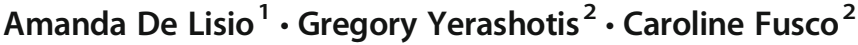

Received: 31 August 2018 / Accepted: 28 November 2018 / Published online: 9 February 2019

(C) The Author(s) 2019

\begin{abstract}
There has been recent academic attention focused on youth geographies. This literature has worked to emphasize youth experiences in urban life. Concomitantly, there has been a bourgeoning body of research directed at the evaluation of the sport mega-event as a catalyst of urban-spatial reform that has questioned the role of sport in the design of socially-equitable and environmentally-sustainable cities. In this paper, we examine the intersection between geographies of youth and the sport mega-event. Specifically, through a qualitative document analysis of relevant sport mega-event documentation, we compare and contrast written material with a thematic analysis of qualitative data collected with a small sample of newcomer youth in Toronto, Canada. Ultimately, we aim to explore the manner in which event-linked development priorities (and associated ideologies) manifest transnational (elite) representations of space through sport, and in turn, reconstruct urbanspatial fantasies of citizenship in the supposed diverse and inclusive "host" context. Our qualitative data demonstrate the extent to which the everyday places of newcomer youth, so filled with their own hope for the future, are most readily experienced as a perpetual negotiation between strategic exclusion and repressive inclusion - or the future otherwise envisioned for them.
\end{abstract}

Keywords Newcomer youth · Sport mega-event $\cdot$ Hospitality $\cdot$ Neighborhood change $\cdot$ Toronto, Canada

Amanda De Lisio

adelisio@bournemouth.ac.uk

1 Faculty of Management, Bournemouth University, 158 Brunswick Ave., Toronto, Ontario M5S 2M5, Canada

2 Department of Exercise Sciences, Faculty of Kinesiology and Physical Education, University of Toronto, Toronto, Ontario, Canada 


\section{Introduction}

The welcoming of an internationally-recognized sport mega-event, in demanding the construction of hypermodern sport, recreation, and leisure facilities, will disrupt material (e.g., neighborhood change, architectural design, traffic flow, etc.) as well as immaterial (e.g., public policies, strategies of place-based citizen renewal) urban order. Rather than accept the promise of economic prosperity and international recognition, more work is needed to ensure that sport/event-prompted development does not exacerbate the social, economic, environmental or recreation and leisure inequalities existent within host communities. We approach the sport mega-event as a microcosm to examine the intricate processes and people involved in the (re)construction of urban life in contemporary cities - (re)construction that will redefine opportunities for youth labour and leisure. As an avid candidate for the 1960, 1964, 1976, 1996, and 2008 Olympic Games and eventual host of the 2015 Pan/Parapan American Games (TO2015), Toronto, Canada, served as a crucial site to examine development priorities celebrated via event construction (or destruction) as well as the associated impact on local youth. In this article, we examine the manner in which development ideologies - fantasies of a future Toronto-(re)write host realities, particularly for newcomer youth living/working in St. James Town, a neighborhood located in the northeast corner of the downtown core.

This research resulted from our shared interest in sport as a malleable realm for politicaleconomic advancement and influencer of socio-spatial realities of newcomer youth living, working, and playing in a particular urban corridor of Toronto. We focus on newcomer youth to better understand the manner in which young people claim space and carve an existence within the context of (shadow) host communities - or communities on the literal fringe of festival space. As part of a larger study entitled the "Neighbourhood Change Research Partnership," we participated in the Urban Youth Working Group that brought together academics from Criminology, Education, Social Work, and Kinesiology as well as youth-serving organizations and community partners. The collective goal of the Urban Youth Working Group was to advance an understanding of opportunities and risks faced by youth in the Greater Toronto Area (GTA) and further the NCRP research objectives (as outlined on the website http://neighbourhoodchange.ca). Due to the limited literature on newcomer youth in mega-event host cities as well as our location within an academic institution that acted as consultant and direct benefactor of TO2015, we were compelled to further interrogate the unintended social and spatial legacies on newcomer youth in the immediate area.

\section{Sport-Sponsored Neighborhood Change}

As host of TO2015, Toronto offered an opportune site to compare and contrast dominant discourses that rationalize (and indeed mobilize) rapid urban reform in pursuit of an internationally-recognized event with lesser-known local realities. ${ }^{1}$ Excited to welcome

\footnotetext{
${ }^{1}$ The Pan/Parapan American Games is a major international multi-sport event held on a quadrennial basis among countries in the Americas. Host cities are contractually-obliged to organize and fund the event in a manner consistent with the Olympic Charter. With 6132 athletes representing 41 National Olympic Committees, across seventeen venues in the province of Ontario, to-date TO2015 was the largest sport event ever hosted in Canada.
} 
and host an international audience for a moment of selective (seldom collective) celebration, transnationally-minded elite harnessed the impression of Toronto as the most inclusive and diverse host in the world (as evidenced below). At the same time, Canada was positioned in the midst of an immigration debate; exacerbated with the campaign for federal office south of the border. Prior to TO2015, U.S. presidential candidate, Donald Trump, announced his campaign with a particularly divisive platform on immigration. As a newly-spotlighted destination for newcomer communities, federal authorities in Canada summoned national mythologies of inclusion and multiculturalism - mythologies that were enthusiastically endorsed in official TO2015 material - to further propagate the vision of Canada as the friendlier neighbour.

Important to our research is the manner in which sport is implicated in this vision. Often regarded as a commercially-viable and socially-pacifying institution, sport is resourced in the (re)development of postindustrial world-class cities, promising the injection of global-tourism capital, increased access to sport, recreation, and leisure facilities as well as the realization of (supposedly) more environmentally-sustainable transit opportunities (see, for example, Veal et al. 2012; Nitsch and Wendland 2017). As a facilitator of public-private collaboration, sport has catalyzed entrepreneurial strategies that work to decentralize state-funded activities via privately-run and contractuallydelivered processes (Oliver 2017). Indeed, throughout the literature, sport is repeatedly implicated in the "competitive city model" (Boudreau et al. 2009; Kipfer and Keil 2002; Silk and Andrews 2012a) wherein postindustrial cities harness event enthusiasm as an added chance to realize neoliberal itineraries, i.e., accelerate processes of state-led securitization/militarization, marketization, and privatization through regulatory capitalism (see also Raco 2014). Reminiscent of processes observed in Vancouver (Vanwynsberghe et al. 2013), London (Raco 2014; Silk 2014), and Rio de Janeiro (Richmond and Garmany 2016), neoliberal sensibilities and itineraries continue to inform sport/event-inspired urban renewal: "soft power" strategies that are thought to accelerate the entrance of host cities into global economies (Grix and Houlihan 2014). In such a context, sport is mobilized as an avenue to accelerate certain political-economic fantasies through liberal-progressive sensibilities within attendant host communities.

Recent research on the sport mega-event has examined development priorities and realities in the midst of time-sensitive construction processes. This work has interrogated the impact of the event on social legacies (Kidd 2013; Lenskyj 2012; Vanwynsberghe 2015), national identities (Broudehoux 2017; Silk 2018), urban geographies (Gaffney 2010; Oliver 2017), recreation and leisure opportunities (Potwarka and Leatherdale 2016), political dissidence (Boykoff 2014), and environmental collapse (Geeraert and Gauthier 2018). As a microcosm of broader societal trajectories and itineraries, the sport mega-event is not removed from the cultural preoccupation with terrorism; the fear from which has worked to legitimate and indeed necessitate the militarization of urban space. Sociological work on the sport mega-event has demonstrated the manner in which counterterrorism strategies have worked to sanitize and securitize festival spaces (see especially Atkinson and Young 2012; Boyle and Haggerty 2009; Cornelissen 2011; Giulianotti and Klauser 2010; Falcous and Silk 2010; Schimmel 2012a; Silk and Manley 2017). To such an extent, it is argued that sport has facilitated the otherwise insidious military-police assemblage wherein heavily-armed police personnel are called to defend against foreign threat on domestic land. Prouse (2013) has importantly illustrated the impact on youth. That is, mega-event strategies leverage the figure of the migrant youth - predominately racialized and male — as personified villain and 
target. Whilst the imposition of mega-event "technologies of surveillance" (Foucault 1977) are believed to be a moment of exceptionalism, surveillance legacies remain well after megaparties end (see also Fussey and Coaffee 2017). These legacies provoke us to take serious the material, symbolic, and affective indeibilities of securitizing processes; even if the event is largely conceived as a one-time moment in urban life.

With our shared emphasis on youth, we want to further acknowledge the work to examine the impact of the sport mega-event (and associated construction) on children and youth; particularly with respect to sport, recreation, and leisure opportunities (Potwarka and Leatherdale 2016; Veal et al. 2012). We especially note the critical contribution of Kennelly (2016), Kennelly and Watt $(2011,2013)$, and Watt $(2008,2013)$ which has significantly informed our approach. Through the collection and analysis of qualitative data from 2010 Vancouver (Canada) and 2012 London (England) Olympic host communities, Kennelly and Watt demonstrate the detrimental impact of newly-enacted Olympic legislation and heightened securitization on marginalized youth. In the case of Vancouver, stories from young people detail the lived realities of new legislation such as the "Assistance to Shelter Act" (enacted 26 November 2009), which allowed local law enforcement to use "reasonable force" to transport a "person at risk" to a homeless shelter. ${ }^{2}$ Vancouver youth articulate the impact of this newly-enacted legislation designed to erase so-called abject bodies from Olympic view and further mark street-involved young people as undesirable, criminal, and disposable (Kennelly and Watt 2011, 2013). In the case of London, neoliberal policies such as the 2011 Localism Act, intended to facilitate the devolution of power from central (national) government to local communities, created the condition in which urban space was restructured through private entities. Whilst public space was restructured vis-a-vis corporate-economic interest, youth noted an increase in police harassment, surveillance, and arrest (Watt 2013). ${ }^{3}$ In Vancouver and London, local authorities were shown to use these newly-imposed policies to direct surveillance strategies at homeless or low-income youth on land now ripe for renewal. These strategies - which mimic "accumulation by dispossession" (Harvey 2008: 64) - are not exceptional to the sport mega-event but reflective of the historic effort to sanitize urban space from "space invaders" (Puwar 2004: 8) or those discursivelyperceived to pollute the body politic (Goldberg 1993; Razack 2002). As we demonstrate next, inherent within these strategies is the idea that urban space is never blank or neutral. In recognition of our shared commitment to young people, we wanted to know the extent to which newcomer/immigrant youth in (shadow) host communities make sense of ideologically-entrenched (never blank) space and attendant subjectivities or fantasies of a Toronto not-quite realized.

\section{Space, Youth, and Leisure}

We intend to add to the literature that has privileged the perspective of young people to demonstrate that mega-cities manifest, indeed cement, broader cultural sensibilities into the local landscape. The urban condition — its people, architecture, landscape, and design — is a

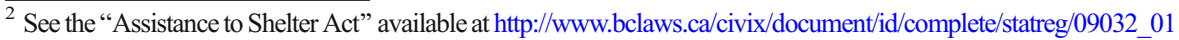
(Accessed 10 May 2018)

${ }^{3}$ See the "Localism Act 2011" available at: http://www.legislation.gov.uk/ukpga/2011/20/pdfs/ukpga_20110020_en. pdf (Accessed 10 May 2018)
} 
material site through which to examine dominant imaginaries of space/place especially as related national mythologies. Bodies of land, bodies of people are co-created, bounded, and sustained in the spatiotemporal flux of urban life. Existent literature which has cited the work of Lefebvre (1991) (i.e., The Production of Space), has illustrated the manner in which urban space is reproduced through the interaction of material (perceived), institutional-ideological (conceived), and affective-symbolic (lived) realities associated to urban life (Kipfer 2008). Sociological work has continued to emphasize the importance of space and place in youth daily life (Cox 2015; Giardina and Donnelly 2007; Green and Smith 2016; Nakamura and Donnelly 2017; Wright and Macdonald 2010). This literature has recognized that urban space is the materialization of hegemonic power to which youth geographies, particularly those on the fringe of more celebrated urban life, demonstrate little exception (Aitken 2001; Dillabough and Kennelly 2010; Fine and Ruglis 2009; Philo and Smith 2003). Whether examined from the perspective of corporatization (Borden 2003; Farrugia 2017; Holloway and Valentine 2000), moralization (Valentine 1996; Wortley and Owusu-Bempah 2014) and/ or militarization (Giroux 2004; Gallagher and Fusco 2006), there is agreement that whilst "public spaces are universally accessible to a civic public...gendered and racialized identities still function to constrain participation in the public sphere" (Ruddick 2014: 7). This is especially salient in the (limited) place/space reserved and maintained for/within low-income communities (Cox 2015; Dhillon 2017; Sirin and Fine 2007). Not to mention the welldocumented and sustained suspicion of young people in public space whether for leisure or otherwise (Alexander et al. 2018); a preoccupation that is disproportionately directed at racialized youth (Fleming 2016; Foley et al. 2013; Fusco 2007, 2012; Hartmann 2016; King 2007). Throughout this research, we thus worked to follow the critical mass of scholarship in geographies of youth and leisure to further prioritize youth-centric approaches to urban life and demonstrate the manner in which newcomer youth articulate and navigate the lived constraint/contradiction between event enthusiasm and (sport-sponsored) gentrification/ neighborhood change.

\section{Welcoming the World or the Socio-Spatial Limit of Hospitality}

From the creation of the Bid Book to the construction of the final stadium, host countries, cities, and select/representative personalities are involved in a publicity exercise. Essential to this effort is the impression management (Goffman 1956) of host communities as (unsurprisingly) hospitable (see also Hubbard and Wilkinson 2014). While we recognize academic work has focused on the production of festival/event space within (supposedly) host cities, we also maintain that this literature has somewhat un(der)theorized the notion of hospitality. To our definition of urban space as ideologically-entrenched and materiallynegotiated, we thus want to add a definition of hospitality as outlined in the work of postmodernist theorist, Jacques Derrida. To Derrida (1999), hospitality is treated as an "ethic without law" that does not "belong to the order of the political, or at least not simply to a political space" (49). Inherent to his theorization is the philosophical and ethical impossibilities of hospitality that come to mark the encounter and relation between host-guest, citizenforeigner, etc. According to Derrida (2006), the principle of hospitality is to create "welcome without reserve and without calculation, an exposure without limit whoever arrives [l'arrivant]" (6) and it implies a transformation of law and language; experienced as an interruption to the self. This is the approach to hospitality that is viewed as possible - indeed 
contractually necessitated by - tourist classes and Olympic/FIFA families. Research on the sport mega-event has demonstrated the extent to which host cities rewrite domestic law and suspend national language/custom to accommodate official parties involved in the megamoment. Whilst those most in need - despite named the immediate benefactor of sport/ event-prompted development - continue to receive a welcome that is discretionarily afforded, confined, and controlled. We thus want to emphasize hospitality as never without a socio-spatial limit or never "without reserve and without calculation" (2006: 6) as Derrida envisioned. Youth illustrate the manner in which the limit of hospitality has everyday material propensities that demarcate urban boundaries and associated bodies (see especially Dikeç et al. 2009). As we work through our analysis, we focus on the manner in which urban imaginaries and associated construction that privilege the external tourist market also inadvertently reconfigured the lived limit of hospitality for disenfranchised youth. As youth seek to negotiate everyday life in (supposedly) host/hospitable cities, all around them processes of urban regeneration seek to redress the spatial limit of hospitality. Through the globallycelebrated event, young people encounter the inherent dilemma of hospitality - that is, the fact that whilst some enjoy the benefit of connection and enhanced mobilities in this globalized moment, more remain locked or forced into place/movement. It is this condition in which infrastructure and regulation is called to create hospitality for some yet, also, further demarcate the bodies of people, bodies of land outside official festival space. Processes that are inhospitable at best.

\section{Methodology}

\subsection{Spatial and Political Context}

The enthusiasm directed at a one-time event must be considered within socio-spatial histories of host cities - in this case, Toronto as a (supposed) multicultural home to newcomer families. With an estimated population of 2.8 million people (5.5 million in the broader metropolitan area), Toronto is the largest city in Canada, and has occupied a hegemonic position in the national economy since 1930 (James 2010). According to Statistics Canada (2011), foreign-born people account for nearly half of the population of Toronto; the second highest percentage in the world next to Miami. Toronto is also host to more than one-third of the Canadian newcomer population. As evidenced in the recent work of Ahmadi $(2017,2018)$, the rhetoric of a multicultural and diverse Toronto has continued to serve political parties in power whilst also limit the authentic impact (especially as realized through economic redistribution, social justice, and anti-racism) on marginalized communities. The emergence of St. James Town and Regent Park, as one such material illustration, occurred in reaction to (i) the federal/provincial government desire to (appear to) prioritize public housing; and (ii) the de-racialization of Canadian immigration policy (Boudreau et al. 2009). From 1997 to 2004, much attention was directed at the concentration of racialized poor (figured as foreigner/ immigrant) on behalf of local authorities - from the United Way, the Toronto Board of Trade, and the City of Toronto (Saberi 2017). The death of Jane Creba, a 15-year-old girl, shopping near the commercial intersection of Yonge and Dundas in December 2005 further propelled a rhetoric of criminalization in communities otherwise stateabandoned with a \$51 million-dollar investment, intended to address gun/gang-related 
crime via added police surveillance (Zuberi and Taylor 2017). The heightened police presence in such communities marked the area (and people within) as primed for erasure and development (Saberi 2017). The reliance on a private mega-project to develop needed residential properties in the downtown core, also accelerated at this time. The Regent Park revitalization project funded through private investment (i.e., Daniels Corporation) started in 2006 (Johnson and Johnson 2017). In September 2012, the Maple Leaf Sports and Entertainment (MLSE) Foundation joined this effort to construct three recreation and leisure facilities in the area (MLSE Foundation 2015). The $\$ 735$ million construction of the TO2015 Village was another iteration of a privately-funded large-scale urban project in the same corridor. Not unique to Toronto - albeit evidenced across sport mega-event literature - the rhetoric of social mix, combined with the criminalization of unwanted communities, served to rezone and refashion lucrative land (Johnson and Johnson 2017). Important to our research is the manner in which youth in this TO2015 celebrated corridor are implicated in liberalprogressive sensibilities, which harness sport as a facilitator of urban development. To follow the work of Bellas and Oliver (2016), the involvement of an international sport conglomerate in the redevelopment of Toronto was "predicated upon a process that removed politics in order to be more effective" (678) and thus eradicated the democratic need for "deeper social commentary" (686). Situated in the literal shadow of TO2015 construction, we focused on the discursive and material incursion of sportprompted development on young people in that urban corridor; particularly, as related to their future access to labour and leisure. It is due to the fact that this neighborhood served so prominently in TO2015 imaginaries - combined with an established network in the area through the long-term work of one author as well as our involvement in the Urban Youth Working Group - that this research was first conceived.

\subsection{Data Collection and Analysis}

As indicated above, previous research has demonstrated the extent to which sportsponsored neighborhood change has failed to reconcile the class-based racial inequalities that continue to define mega-cities. We were thus interested to examine the manner in which marginalized youth experience and negotiate neighborhood change in Toronto. This specific neighborhood is one of the last to be gentrified in the downtown core (See Fig. 1). We focused on the southeast corridor from the newlyconstructed neighborhood nearest Lake Ontario, known as the Canary District (former TO2015 Village) and Corktown, east of the Don Valley Parkway and west of Sherbourne Street, to the north neighborhood of St. James Town, nearest Bloor Street (See Fig. 2). ${ }^{4}$ We understood TO2015 development as a gateway to explore the connection between sport, recreation, and leisure in conjunction with the

\footnotetext{
${ }^{4}$ In 2016, the Canadian permanent resident admission was 296,346 people - the highest ever — with a target of 300,000 people in 2017 (Citizenship and Immigration Canada 2017). Within the current real estate market in Toronto, most newcomer families cannot afford home ownership and thus depend upon rent-controlled private rental stock. Research has also shown that race, gender (particularly with respect to young men), ethnicity, and religion all limit access to affordable (rental) properties in Toronto (Dion 2001; Hulchanski 2010; Murdie 2008). This has resulted in the concentration of racialized, low income families in the southeast corridor of the downtown core. An estimated 65,000 people (mostly visible minorities) live within the square kilometer neighborhood known as St. James Town (Statistics Canada 2011).
} 


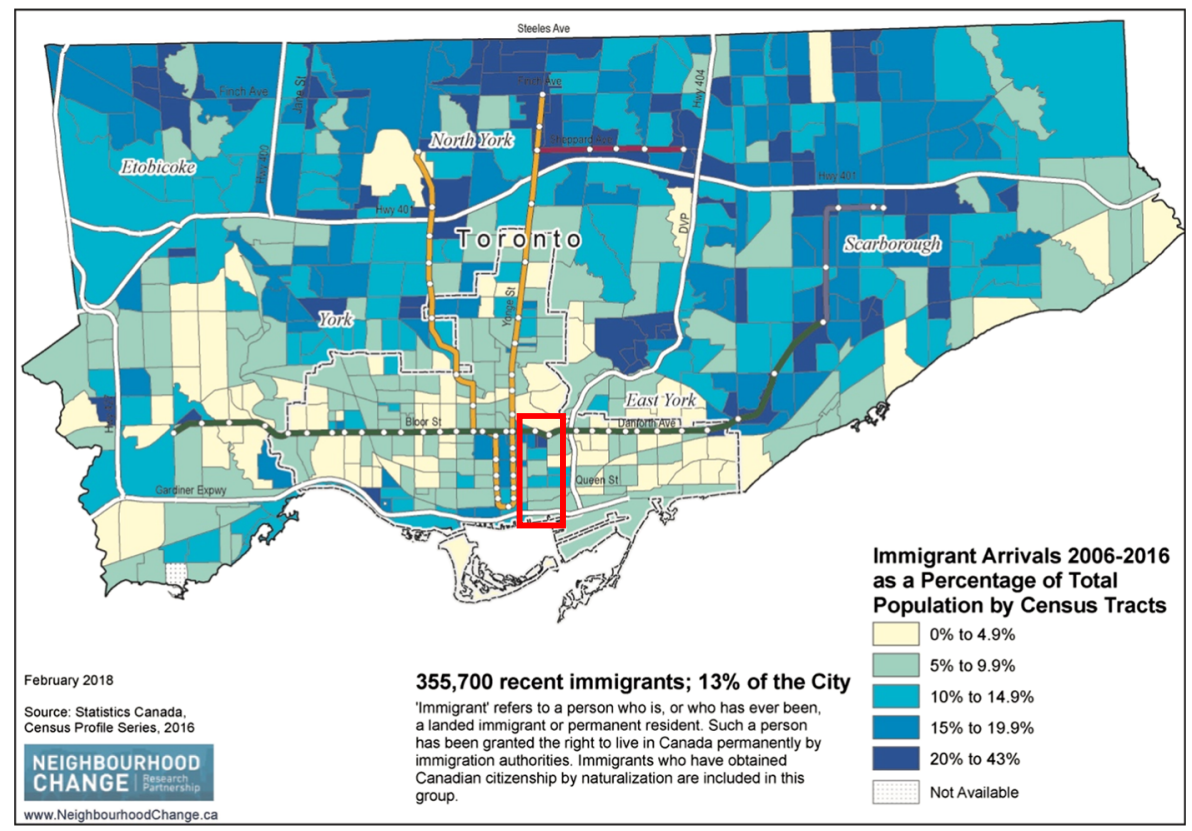

Fig. 1 Recent immigrants, 2006-2016 arrivals, City of Toronto, 2016

(re)development of the area, and the extent to which broader socio-spatial processes impact realities and opportunities for newcomer youth. In line with the literature that has worked to amplify youth voice in urban processes (Kennelly 2016; Kennelly and Watt 2011, 2013), we examined the discrepancies between the discursive construction of TO2015 communities through official event material and the lived-realities of a sample of youth in the southeast side.

To follow the work of Fusco $(2007,2008)$, we relied on several interrelated methodologies to trace the flow of power in the (re)production of urban space and subjectivities. First, a critical qualitative document analysis (Altheide et al. 2008) of relevant TO2015 and event-related material was conducted to determine the production of knowledge and ideologies in reference to space. This was collected in conjunction with visual (photographic) data needed to document the material space incorporated into social imaginaries and which fueled dominant fantasies of a future Toronto. One author also served as an outreach worker and volunteer coach in the neighborhood - through their access, observational and interview data was collected between May 2017 and February 2018. For the purpose of this article, we limit our analysis to TO2015 Bid Book, Host City Contract, and promotional material as well as the observational and semi-structured interview data collected with young people from St. James Town (Toronto).

All youth interviewed were aged between 18 and 21 and were either first or secondgeneration immigrant-children in Canada. We targeted this narrow age range to focus on young people near the completion of high school (and the associated leisure) with interest in formal employment. Youth hailed from countries all over the world, including Somalia, Ethiopia, Eritrea, Ghana, Algeria, Bangladesh, Sri Lanka, Iran, Uzbekistan, and Russia - all had Canadian citizenship with the exception of one who 


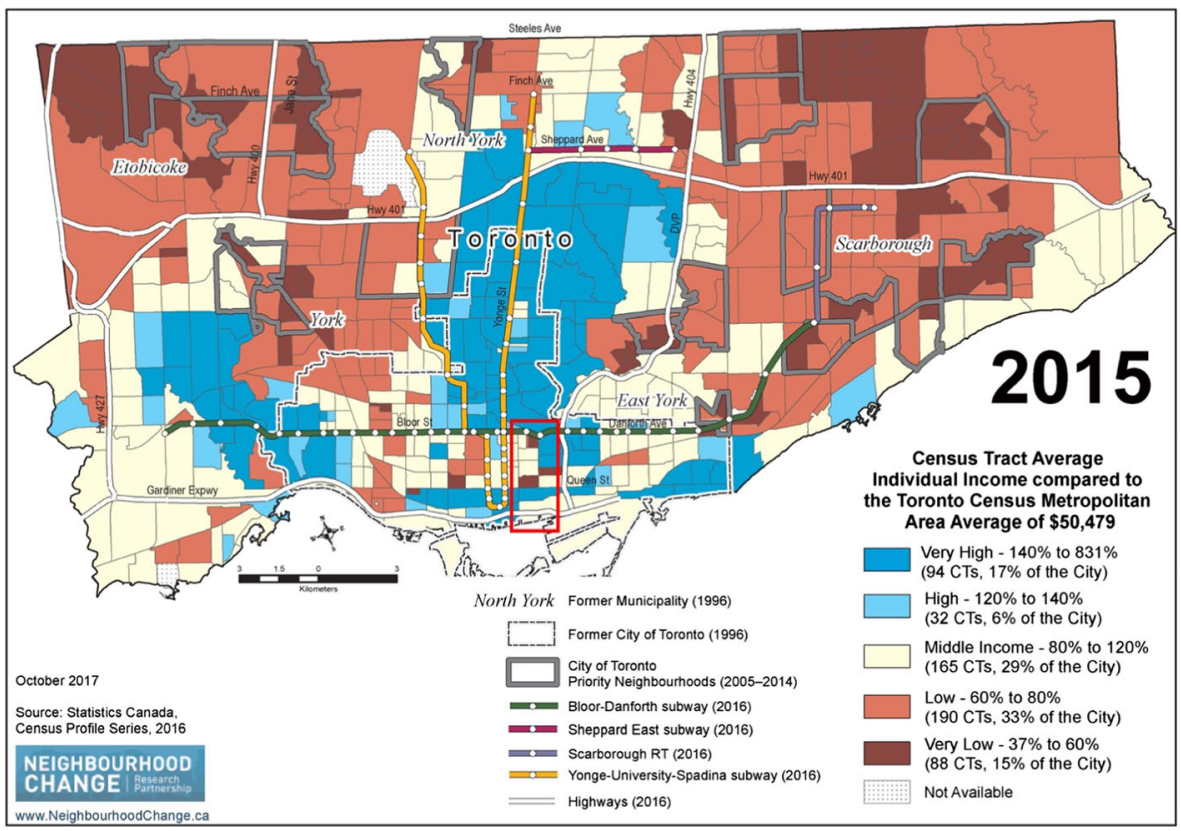

Fig. 2 Average individual income, City of Toronto, 2015

maintained the status of permanent resident. Eight male-identifying youth were individually interviewed for approximately 1 hour whereas the three female-identifying youth (who choose to be interviewed as a group) were interviewed for a 90-min period. Each participant self-selected their cultural identifier (e.g., Muslim-Canadian, Sri Lankan-Canadian, etc.) used throughout this text. In order to facilitate conversation, a semi-structured interview guide encouraged young people to discuss neighborhood change, access to (recreational) urban space as well as opportunities for leisure and labour. Throughout data collection and analysis, we aimed to compare and contrast official narratives associated with the event (as evidenced in TO2015 documentation) with the everyday lived realities of newcomer youth. We read through the data with this initial intention in mind before we could refine, revise, and further develop each theme explored below.

Data collection followed our university-approved ethical protocol and as such, required that interview data be transcribed verbatim, and anonymized. Youth were informed of the process and confirmed participation through written consent. Anonymous interview data was then shared with each author whom collaborated on the coconstruction of each thematic code (e.g., exclusion, securitization, celebrated citizen) to further compare and contrast with relevant event material. This allowed us to compare/ contrast dominant fantasies - i.e., conceptions and imaginaries of space - propagated in the mega-event rhetoric with the everyday lived realities of place articulated and observed in our interaction with the newcomer youth. The stories of young people in St. James Town reveal much about the inextricable nature of urban space, bodies, and power in the shadow of a sport mega-event. The remainder of this article will explore these geographies of (newcomer/immigrant) youth in relation to the TO2015 urban imaginaries, neighborhood change, and socio-spatial exclusion youth experienced. 


\section{T02015 Fantasies and Youth Realities}

\subsection{Imagined Geographies and Neighborhood Change}

For host communities within Toronto, the mega-event promised to reimagine space and attract private investment to manufacture a "happy middle class future" (Hume 2014) and resolve: (i) jurisdictional fragmentation resulting from competing responsibilities of various public and private agencies (Kipfer and Keil 2002); (ii) the continual decline of industrial factories and port-related industries; (iii) the economic possibilities for nonindustrial land or rather concern over the privatization of the Toronto Waterfront (Desfor and Laidley 2011). Indeed, the legacies outlined in the TO2015 Bid Book affirmed a desire to stimulate renewal on the once barren and toxic (Lake Ontario) waterfront vis-a-vis the inclusive potentialities of sport as "one of the most powerful ways that this multicultural society has taught and united its children, youth and communities" (2009: 3). Chair of TO2015 Host Committee, David R. Peterson announced, "[t] hese Games will, no doubt, be a celebration of sport and culture, but they will also be a region-building exercise, one that will be remembered by this generation who help shaped it and the generations to come" (TO2015 2013: 2). Moreover, the provincial Minister of Municipal Affairs in power at that time stated: "The McGuinty government continues to build affordable housing across the province to meet the needs of individuals and families. I'm pleased that our investment in the 2015 Pan Am Games will help create a vibrant, diverse community that so many deserving people will call home" (Minister of Municipal Affairs 2012, para. 5). Yet event construction of local land does not evade contestation and contradictionfuturities conflict and contradict - first as fantasies and then, constructed realities. For example, despite the promise to create mixed income/tenure properties, some subsidized to target low-income families, former Mayor of Toronto, Rob Ford, scoffed at the proposal to use "prime property" on the waterfront for affordable housing (CBC News 2013). The rhetoric of inclusion would need to be negotiated within a neighborhood that would serve as a "state-of-the-art oasis" for competition (Infrastructure Ontario 2011) and "showcase a modern community where design excellence, sustainability and technology come together" (Waterfront Toronto 2011, para. 4). Certainly, these (conflicted) imaginaries illustrate the type of space conceived for TO2015 host communities - economic and political imaginaries which were to inform the construction of a future Toronto - in the absence of families and communities already housed within that exact area. In reaction to TO2015 imaginaries that celebrated a more inclusive future, young people in St. James Town were aware that the materialconstructed future would ever be intended for them. In response to a question about TO2015 construction, three self-identified Muslim-Canadian youth started to compare/ contrast this celebrated event rhetoric of a more inclusive Toronto with their everyday lived realities:

Youth 1: The PanAm was in my neighbourhood, all those PanAm buildings, apparently, they are supposed to be mixed, that's what I was told, but I feel like that was prime real estate for subsidized, cooperative housing, that's how it should be ... but it's all condos. I have friends who live there and they say it's just a condo. I feel like it should have been more mixed because there's 
opportunity. You need more cooperative housing that's subsidized and you got the opportunity to do so but you didn't, you chose not to ... I don't live in Regent [Park] or St James Town. I live on a street, not a neighbourhood. With condos surrounding it. Condos, everywhere. This just started when I entered high school. Now, my whole neighbourhood. It used to be nice, old brown buildings. (SomaliCanadian, Female, 19)

Youth 3: "Revitalization" (said with air quotes) everywhere, that's what they call it. (Sri Lankan-Canadian, Female, 19)

Youth 1: Yeah, "revitalization" like, more Starbucks? There never used to be a line in my Starbucks, now there's more and more people coming.

Youth 2: I miss old Regent [Park]. I have more memories of how it used to be. The old brown brick buildings. Not these condos. I liked that as a kid. (BengaliCanadian, Female, 19)

Youth 3: I don't like how it's so tall, you know, how the buildings are so big?

Youth 2: Because they are trying to fit everyone in...

Youth 1: Well it makes sense, you can't build wide. There's no space in Toronto, so you build up.

Youth 3: I know but, I don't know... I feel like you can’t see the sky anymore...

Youth 1: I can't see it in my neighbourhood either. From my apartment I see another building from every view. I don't see grass or sky, just condos.

That young people erupted into this discussion midst interview came with little surprise - any universal claim for inclusion is likely to clash with local realities. Nevertheless, one is still struck by the ease in which youth articulate and (forcibly) navigate this contradiction. Youth readily spoke to the disjuncture between local practices (or lived space) and the political and development aspirations (or imagined space) as envisioned by the local elites of host cities. On the one hand, there is enthusiasm to realize inclusive fantasies of renewal yet, youth are well-aware that much of the inclusive-liberal rhetoric will never extend to their communities. Throughout the data, youth noted the manner in which event construction was thought to benefit those with the right to the city-i.e., those encouraged to participate in the urban political system and event moment - and further marginalize those on the urban fringe without such right.

Interviewer: What do you think of all this new development?

Youth 4: I don't like how it's all these condos. Man, the city is just putting condos, condos, condos. There's no recreation space for people or anything ... They just want to cram all these condos everywhere. It's not nice, you know. It's like you're looking up and all you see is concrete, a concrete jungle ... Like, you don't want to see that. You want to see trees, nature. (Eritrean-Canadian, Male, 20)

Interviewer: What about the changes... What do you think?

Youth 5: They built the [PanAm] Village down the street, renovated it, cleaned ... But they didn't really touch anything in St. James Town. So, they really only developed things to make the city look better for the tourists ... Mostly downtown Toronto ... Like it is good they built some of these facilities but like, I don't see a local development effort, like that Olympic pool they built ... Kids around here can't afford to get all the way down there! (Algerian-Canadian, Male, 21) 
Despite the recent effort to realize recreational opportunities, which are much needed in this particular neighborhood, youth could not afford to travel to access new amenities - cost (unsurprisingly) mitigated access to the new state-of-the-art facilities. Again, this is not unique to Toronto or TO2015. This is a consistent failure of host cities that promise new opportunities for labour and leisure in communities of need (Kennelly 2016; Kennelly and Watt 2011, 2013). Schimmel (2012b) observed that in the context of neoliberal, state-sponsored urban renewal, "stadiums often exist in close proximity to citizens who cannot afford the price of admission and who disproportionately bear the burden of increased taxation" (pp. 171-172). The youth that participated in this research were likewise forced to live this proximity and were thus not barred from the obvious contradiction. One young person especially noted the missed opportunities for recreation in his own neighborhood - an area in dire need of green space:

Youth 4: Like, they could build us a field. I mean, they built a turf field there [Regent Park]. It's really nice. It's got beautiful turf, real nets with mesh, and we want them to bring something like that to our community. Our turf field went down the drain. The lining is ripping. The turf is starting to flatten to carpet. It rips your shoes, your knees, and ankles. Plus, there's no light! I don't think they meant to put good quality in a community like this... Maybe if it was Rosedale or Forest Hill they would put in the best turf available but here, they knew this field wouldn't be maintained, wouldn't last forever so they put what was suitable for here. (Eritrean-Canadian, Male, 20)

Overall, youth were aware of the imaginaries of urban reform and even endorsed the future vision advertised but remained disappointed in the manner in which these fantasies materialized. This is not to suggest leisure opportunities are never afforded to/for youth in Toronto. There are many policies (federal, provincial, municipal) and recreation/leisure agencies that seek to increase youth participation (see especially Rodericks et al. 2018) yet these "seemingly benevolent discourses about play and physical activity ... [continue to] be connected to neoliberalist conceptions of health and wellness in the city" (Fusco 2012: 153-154) that prefigure youth as responsible for their own health despite obvious structural complexities. With respect to TO2015, if consultation had occurred, it would have been evident that young people in the southeast corridor perceive sport/recreation as a critical component of(re)settlement. Young people readily expressed this in conversation - informal involvement in sport served as an important stress reliever and/or community creator. One youth from Accra, Ghana, stated: "I love soccer ... I love to watch it, play it, talk about it ... It takes away stress and brings me closer to people ... I had no friends when I came here but I made friends and learned the language and culture through sports ... It opens doors you know" (Male, 22) yet, without basic facilities, participation also reinforced disparities between youth in St. James Town and those in wealthier (proximate) communities. ${ }^{5}$ As another young person later commented, "I feel like sport in Canada is a business ... if you are

\footnotetext{
5 Important to note that, St. James Town, an area of dire economic need (i.e., median private household income below \$52,149), is situated next to some of the richest census tract communities in Toronto-namely, Rosedale and Forest Hill (private household income estimated at \$419,676). See also, Tulk, C. \& Grzincic, N. (9 November 2017). Do your neighbors make more than you? Search our map of income in the GTA. The Toronto Star. Available at https://www.thestar.com/news/gta/2017/11/09/do-your-neighbours-make-morethan-you-search-our-map-of-income-in-the-gta.html (Accessed May 8, 2018).
} 
financially stable, you are able to participate and enjoy ... there are opportunities for wealthier kids but we are limited" (Algerian-Canadian, Male, 21). In an attempt to overcome participation-related disparities (i.e., cost of registration, equipment, travel, etc.), young people prioritized labour or the economic opportunities (perceived to be) associated with the event. So, whilst we initially thought leisure would serve as the main topic of conversation, labour became an important theme to further interrogate.

\subsection{Repressive Inclusion: The Securitization of Celebration Space}

"Programs will give young people practical job skills and opportunities to put those skills to work in all aspects of Games organization and delivery" (TO2015 Bid Book 2009: 201).

In this section, we zone in on the manner in which newcomer youth were called to participate in the event moment through employment opportunities. Previous work has documented the extent to which racialized, low-income youth are subject to heightened "pacification strategies" in the context of the sport mega-event. For example, prior to the 2014 FIFA World Cup and 2016 Olympic Summer Games in Rio de Janeiro, Brazil, "pacification" police (i.e., Unidade de Polícia Pacificadora) were installed across lowincome communities, which worked to securitize lucrative land through cultural and spatial strategies (Steinbrink 2014). Not unique to Brazil, TO2015 imaginaries were realized through a similar continuum of heightened police presence and more subversive humanitarian rescue (see our earlier comment about the refugee crisis) - expressed as a balance between liberal peace (as the biopolitical, therapeutic dimension) and staunch militarism (as the political-economic dimension) (Amar 2012). These echoed the strategies of pacification also employed in London and Vancouver that criminalized anti-social behaviour and communities (Kennelly and Watt 2011, 2013) which proved far from the 'trickle-down effect' examined in the work of Potwarka and Leatherdale (2016). For TO2015, \$182 million was dedicated to event securities. This covered the cost of provincial (Ontario Provincial Police), federal (Royal Canadian Mounted Police), and municipal police (Toronto Police Services) as well as a private security force. ${ }^{6}$ With such a surge in budget, evident in the influx of uniformed men, the issue of event securities was indeed a recurrent theme throughout data. Two young women described their experience in their newly-securitized urban corridor:

Youth 2: I remember one time I was sitting outside of a building on Cole Street [in Regent Park Area] and they kicked me out because they say, "it is private

\footnotetext{
${ }^{6}$ The private firm that won the TO2015 security contract was Contemporary Security Canada, a division of the California-based Contemporary International. The same private security firm was contracted for the 2010 Winter Olympics (\$164 million contract) in Vancouver as well as the (2010) G8 Summit and G20 Summit (\$21 million contract) in Toronto. Importantly, it was fined $\$ 45,000$ - because it failed to obtain adequate license, ensure proper uniform, and hire a licensed guard - for the (2010) G8/G20. Security agencies based in Ontario reportedly bid substantially less but still lost the G8/G20 and TO2015 contract. (See R.J. Brennan, Toronto Star, 26 March 2014) Available at: https://www.thestar.com/news/queenspark/2014/03/26/ndp_ wants_probe_of_pan_am_security_contract_that_went_to_us_firm.html (accessed 5 July 2018)
} 
property". Like, I've been here my entire life and now I'm not allowed to be in front of the building? (Bengali-Canadian, Female, 19)

Youth 3: Yeah, I refuse to sit there anymore because of that, I don't want to sit there anymore. Because, like, we weren't even doing anything wrong. Maybe we were suspicious, eating our Tim Hortons, and [private security] tell us, "We aren't allowed to be there." (Sri Lankan-Canadian, Female, 19)

These stories paralleled the work of Kennelly and Watt $(2011,2013)$ with respect to marginalized youth in Vancouver that, whenever visible, are subject to police dispersal. Across Canada, Public Safety Canada (PSC) has prioritized the surveillance of immigrant, indigenous, and Muslim communities via a National Security Community Outreach Program (NSCOP) with the aim "to establish trust with minority communities and gain their assistance and cooperation in protecting Canada's national security" (PSC 2011: 72 as cited in Monaghan 2014). The globalization of paramilitary strategiesparticularly in relation to event/sport-prompted renewal- has reinforced the perception of (racialized, low-income) youth as suspect, and thereby a target of needed state intervention (Schimmel 2012a). While barred from state-of-the-art recreation and leisure facilities and treated as potential threat, in a somewhat ironic twist, young (some Muslim) men, so-often target of security strategies in Canada and elsewhere (Monaghan 2014), were encouraged to serve as (precarious) private security personnel. Du Toit (2004) has written on adverse incorporation or social exclusion. We see the involvement described by young people as repressive inclusion - in that youth are welcomed to partake in event activities in so much as their presence is required for labour and does not disrupt the neoliberal status quo. As one young man noted in response to our question about the employment opportunities made available via the event:

Youth 5: We got our security license through the Games and then from that license we thought we could get other jobs. It goes on your resume and looks good. So, the Games did offer that positive impact to neighbourhoods and communities and helps people get jobs after so it's a good thing...But I applied for another job with another company after the Games and they looked at where I worked and they looked down on me because the security training we had was absolutely horrible. The other companies knew about our training experience, they knew what was going on...So they really didn't hire people that got their license through the PanAm Games. (Algerian-Canadian, Male, 21)

Despite the effort to showcase the supposed multicultural and racially-ethnically diverse host, one that is able to promote "an environment of inclusion - of broad and sincere involvement of the diverse communities that constitute the mosaic of Canada" (TO2015 2009: 201), marginalized youth shared a different experience. Consistent throughout the data was the sentiment that young people were welcomed to volunteer or participate as overworked-underpaid-employee. This aligned with the realities of racialized youth (un)employment in Toronto wherein the shift from public delivery to privately serviced opportunities incentivized youth to respond in an entrepreneurial manner. Vanwynsberghe et al. (2013) critiqued the benevolent neoliberal rhetoric of the event used to (re)frame structural inequalities as a matter of individual choice. In the context of TO2015, racialized youth were made subject 
to a similar rhetoric and demonstrated an eagerness to overcome (internalized as) personal failure via short-term employment with meager labour protection. This hustle reflected the heightened reliance of racialized youth on precarious labour opportunities made available within the gig economy (Geobey 2013; Government of Canada 2018; Rodericks et al. 2018). Indeed,

... the unemployment rate for racialized youth in Toronto was $23.9 \%$ compared to $19.5 \%$ for non-racialized youth. The unemployment rate for Black youth in Toronto (and Ontario) stood at $28 \%$ which is two times higher than the national average. Many of these racialized youth live in low-income neighbourhoods located within inner suburbs of Toronto. This fact highlights the need to pay close attention to the link between racialized inequalities in youth joblessness and patterns of urban geo-spatial inequality in metropolitan cities like Toronto (Youth Unemployment, Research Project 2016).

These employment opportunities unsurprisingly denied young people the culturallysensitive and appropriate concession to honor cultural/religious tradition. No doubt slippage in the effort to "establish trust with minority communities" as expressed in the TO2015 Bid Book (2009: 201). One participant reflected on the manner in which his employment with TO2015 reinforced cultural difference through insensitive labour strategies.

Youth 5: Basically, they were just hyping up the job and what it would be like. I was in the sun all day. It was also during the month of Ramadan so we were fasting. I told them that we were fasting, we should be breaking at a specific time. Many of the supervisors didn't even care that we were fasting. And often there wasn't enough food by the end of the day left for us ... And I remember waiting in line to sign in, it was so chaotic. I waited for my supervisor in the hot sun until he came to pick me up. They put me into a, well no, it was next to a little tent, and basically told me to stand there and make sure nobody jumped the fence. There were 12 of us in that specific area with that same job and we stood for 10 hours ... Yeah that was our only job. I feel like the security company really hyped up the PanAm Games, cause a lot of people quit their jobs, like their part time jobs to work here. (Algerian-Canadian, Male, 21)

Forced to accept precarious labour opportunities, manufactured as benevolent, youth assuaged insensitivities of those that operated on behalf of TO2015, an organization that was celebrated as diverse and culturally sensitize (TO Bid Book 2009: 3). This qualitative evidence is reflective of the broader statistical trend in Canada that "recent immigrant youth (those in Canada for 5 years or less) still tend to struggle in the labour market relative to their Canadian born peers. In 2011 , only $48.9 \%$ of very recent immigrant youth were employed - compared to 61\% of youth born in Canada" (Government of Canada 2018: p. 23). Moreover, this lack of consideration for cultural/religious difference in the workplace, combined with language difficulties, possessing a non-Canadian accent and/or nonAnglophone name on a resume are all known to limit opportunities for employment and employment advancement among newcomer youth (Social Planning Council of Ottawa 2018; Zaami 2015). Those hired to work as security personnel for the duration of the event were not required to demonstrate prior experience and instead completed a 40-hour non- 
accredited course for a job that generated enormous risk, minimal compensation, and offered inadequate worker protection. Nevertheless, youth prioritized TO2015 employment in order to make the most of the event moment. Evidence of these short-term employment opportunities does bolster the argument that the sport mega-event does create economic benefit yet, as similarly argued in the work of Vanwynsberghe et al. (2013), these also promote an approach to social inclusion that is reliant upon neoliberal entrepreneurialism - form of inclusion that is arguably more repressive or discretionarilyafforded than hospitable. In the next section, we describe the message newcomer youth received from event rhetoric and allied construction with respect to citizenry-i.e., what does the mega-moment, entrenched with cultural sensibilities, teach newcomer youth about their potential placement in (supposedly) host/hospitable cities?

\subsection{Celebrated Citizenry: The Question of Belonging}

Fantasies of urban renewal do not merely (re)envision the city but also the type of citizen that will come to inhabit newly-renovated communities. In addition to the fantasies of a diverse and multicultural Toronto, TO2015 was also thought to inspire a more active future: "The Games will also open the door for more young Canadians to pursue their Pan American and Olympic dreams by putting facilities, coaching, sport science and an intensified competitive culture on the doorsteps of more future champions and record holders" (TO2015 2009: 2). TO2015 was also described as an "incentive" for youth to participate in that it would create "new athletic facilities to Toronto and giving youth opportunities to see world-class athletes will create a new awareness of the various sporting disciplines and the benefits of participation" (TO2015 2009: 201). This rhetoric is well-aligned with the Canadian federal government "Playground to Podium" and "Long-Term Athlete Development" strategies, which seek to deliver future podium success (Fusco 2009). Indeed, sport, embraced as a bipartisan issue, is enthusiastically endorsed across each level of government irrespective of political alignment/proclivities. As evidenced in the Social Planning Council for the City of Toronto (2016),

Recreational activities offer benefits to newcomer youth experiencing the challenges of settlement, including opportunities for newcomer youth to make friends and build support networks in their new country, to practice English, to maintain good health and cope with stress, and to foster leadership and employment skills (2016: 1).

Whilst celebrated as an important part of newcomer resettlement, those responsible for program delivery and implementation were as aware of the complexities that inhibit participation as much as the young people involved in this research (see especially Government of Canada 2016). Young people never discounted the potential of sport in (re)settlement — as alluded to above - it showed them the "example ... that they could make it somewhere if they pushed harder" (Algerian-Canadian, Male, 22) yet, also readily discussed the difficulties with cost, lack of information, language, and infrastructure. Echoed in the literature, these are known to contribute to the lower rate of participation for newcomer youth in recreation and leisure (see also Doherty and Taylor 2007; MacDonald et al. 2009; Taylor and Doherty 2005). The Social Planning Council of Toronto concluded in a report based on the Newcomer Youth Recreation Forum that "budgets need to prioritize things that attract newcomer youth, including music, transit 
fare and culturally appropriate food" and accessible, safer spaces as well as "fees and other related costs are barriers that can prevent youth from attending the program" (Social Planning Council of Toronto 2016: 6). Nevertheless, the repeated failure to adequately address these difficulties made youth even more dismissive of event enthusiasm.

Despite continual reference to the event/sport as a moment to foster "equality, stability and inclusion" (TO2015 2009: 165), dominant imaginaries and associated renewal repeatedly reinforced the sovereign claim/ownership of land and people within. As one youth that identified as Ethiopian Eritrean mentioned, "it was typical ... the rich get richer and the poor get poorer ... and immigrant kids were mostly like what the [explicit] are the PanAm Games" (Male, 20). Two more young people further elaborated on the real-lived influence of the event on their sense of inclusion into Canadian culture:

Youth 4: It kind of hurt me [working security] because I really want to take my game further and to see all the young athletes... When I saw them it hurt me? I was like "Yo, what the hell am I doing working security at a young age. I should be training, I should be there, you know?" But like, I'm only doing this 'cause I need money, right? Like I'm the only one around to help my mom. She can't be working all the time, like she works but I need to pick up my slack. I'm at the age where I need to take on responsibilities, I don't have a father in my life and I need pay for school, and my expenses like cell phone bills, food bills. (EritreanCanadian, Male, 20)

Youth 6: My little sister is 11 years old. She talked about the PanAm a couple times. "The PanAm is happening, let's go outside!" That's it, that's literally it. How can I explain...If you have an interest but you know there's nothing for you, you aren't going to have an interest for very long? It's like propaganda, from commercials everywhere "PanAm Games, PanAm Games in Toronto," and she sees it because she's young, and she wants to go. But we're not going to like, for example, we don't have a car [to get to the facilities] but we took her downtown to watch it at the cinema. That's basically it, we didn't do much, we couldn't do much. (Uzbekistani-Canadian, Male, 19)

Rather than inspire youth to be more active, event enthusiasm served to further reinforced the divide between the celebrated athlete-spectator (encouraged to travel) and marginalized youth (land locked or forced into migration) as also asserted in the work of Kennelly (2016). Youth understood that boundaries (often discursive yet materially imposed) could only be traversed if recognized as the right kind of (neoliberal) citizen. For example, Arthur Biyarslanov was repeatedly referenced as the model "Olympic" refugee. White and war-weary, his arrival in Canada via Azerbaijan was not just for economic salvation but also freedom from terror in his Chechen home. As a resident of St. James Town, his TO2015 bronze medal catapulted him into stardom. Youth that participated in this research shared stories of Arthur as the local hero; celebrated and adorned on national television. His success was made synonymous with the success of the neighborhood as one youth noted, "No one ever talked positively about our neighbourhood until Arthur won. That was a big thing. Once he started to achieve, it was like we all did" (Algerian- 
Canadian, Male, 21). In the same instance, his success re-centred the spotlight on the individual to overcome disparities and carve future success from an otherwise bleak circumstance. Reinforced in the success of Arthur was the perception that (young) people can overcome their personal situation regardless of structural circumstance. Unable to invest in competitive sport, in pursuit of economic advancement, young people instead focused on precarious labour yet still remained skeptical that the event would rewrite (financial) realities.

Youth 5: We were excluded a lot ... Like, to watch, attend, you got to pay... So, it was more well-off families, privileged people. I didn't see one person from around here. And I remember working, there were so many empty seats. (Algerian-Canadian, Male, 21)

Youth 7: From what I know, they would still have to pay to watch the Games, and I'm pretty sure they wouldn't do that because of financial factors. What helped the youth or anyone above 16 was working as a security guard because it was good hours and they made a lot of money off of it, so they made money and were included in that sense ... The reason why I feel like they were excluded is that since Toronto was hosting they gave more attention to the visiting countries. They were more included into everything that were going on during the PanAm as opposed to people who actually live here. (Ethiopian-Canadian, Male, 20)

Whilst often positioned as an apolitical injection of global capital, TO2015 served as an interpellation exercise that celebrated certain host communities and further relegated those outside dominant imaginaries to the urban shadow. As Fusco (2012) has suggested in her discourse and spatial analysis of Toronto recreation policies, sport and recreation has remained "part of a wider neoliberal and even neoconservative strategy to protect and defend hegemonic, normative, and economic interests" (p. 154). This conclusion-i.e., that neoliberalism is interested to collapse local services (e.g., education, recreation, public health) and subjectivities into an economic agenda - is evident throughout academic literature (see especially Alexander et al. 2018; Lipman 2011; Rodericks et al. 2018; Silk and Andrews 2012b) as well as nongovernmental agencies (Canadian Centre for Policy Alternatives 2018; Youth Unemployment Research Project 2016). For young people in St. James Town, the sport mega-event evidently served as one more mechanism wherein this contemporary neoliberal transformation can take place. As outlined in our review of the literature, the transformation associated with sport/recreation has continued to mobilize neoliberal itineraries that celebrate a vision of the urban and associated citizen. Yet criticism of this globally-imagined host has rarely accounted for the lived realities of newcomer youth whom are repeatedly forced to negotiate a life within everchanging regulatory processes. We emphasize the stories of newcomer youth to illustrate the paradox between Toronto as the benevolent host for select tourist classes yet negligent (even hostile) to newcomer families. At the same time, we recognize that the focus on newcomer communities in search of settlement opportunities does little to address those native to this nation now known as Canada - namely indigenous youth from low-income families that are likewise made foreign/other/outside the imagined nation. In a similar fashion, indigenous communities are selectively paraded throughout and insert within event rhetoric yet forced to live without real-direct benefit (Fine and Ruglis 2009; O'Bonsawin 2010). Should this continue, the sport mega-event will further reproduce the circuit of dispossession and 
marginalization that certain communities are repeatedly made to confront in postindustrial development - to reveal the impossibilities of an approach to hospitality that is bound to a rigid and uneven notion of power, property, and possession.

\section{Conclusion}

In this paper we have used the city as a vantage point (Lipman 2011) to discuss the fantasies specific to the TO2015 urban utopia. It is evident throughout documentation produced in promotion of the event that (newcomer) youth are needed to market and sell certain urban fantasies. The intention of this research was to further interrogate the manner in which newcomer youth made sense of these TO2015 fantasies in contrast to everyday lived realities. We suggest that if cities continue to (re)imagine neighborhood change and associated large-scale urban reformharnessing sport as a tool for urban renewal and development (im)possibilities in service of a more diverse and inclusive tomorrow - then future research and policy should seek strategies in which this can be authentically realized. As federal, provincial, and municipal parties fail to adequately address the arrival of newcomer families yet endorse the 2026 FIFA World Cup in Toronto, Canada, we need to remain critical of those that welcome the world for (mega) parties yet ignore those most in need of hospitalities.

In the advertisement of more affordable and inclusive cities, it is important to remain attentive to those whom absolute/unconditional hospitality (as defined in the work of Derrida 2006) is most extended. We conclude that those directly targeted by sport/event trademarkable urban fallacies - despite touted and recognized as the focus of hospitality - do not ever receive the hospitality afforded to tourist classes. Despite fashioned as a multicultural celebration, the realities of newcomer youth in TO2015 shadow host communities reveal a different (albeit familiar) narrative — one of repressive inclusive, securitization, and limited access to imagined communities. Whether via the sport mega-event or not, cities continue to be (re)designed in the vision of neoliberal sensibilities and itineraries. Whilst we are aware of this pattern from the literature (see especially Schimmel 2012b; Silk and Andrews 2012b; Silk and Manley 2017; Watt 2013), it is still difficult to hear youth articulate the primary effect of such processes: intensified class-based racial inequalities. Youth-albeit young and supposedly inexperienced-demonstrated to us that they absolutely understand that event/sport-sponsored development is done with certain communities (and associated subjectivities) in mind and that TO2015 reinforced and maintained socio-cultural hierarchies. The failure to build more inclusive host cities does more than bar youth (most in need) of certain material realities, it is an active deterioration of the optimism needed for tomorrow - the optimism needed to realize a more hospitable future.

Acknowledgements We would like to thank the young people that took the time to participate in this research as well as the Social Sciences and Humanities Research Council of Canada which funded this research through the Neighborhood Change Research Partnership based at the University of Toronto (Principal Investigator, Professor J. David Hulchanski). 
Open Access This article is distributed under the terms of the Creative Commons Attribution 4.0 International License (http://creativecommons.org/licenses/by/4.0/), which permits unrestricted use, distribution, and reproduction in any medium, provided you give appropriate credit to the original author(s) and the source, provide a link to the Creative Commons license, and indicate if changes were made.

Publisher's Note Springer Nature remains neutral with regard to jurisdictional claims in published maps and institutional affiliations.

\section{References}

Ahmadi, D. (2017). Serving diverse communities: the role of community initiatives in delivering services to poverty neighbourhoods. Cities, 69, 86-94.

Ahmadi, D. (2018). Diversity and social cohesion: the case of Jane-finch, a highly diverse lower-income Toronto neighbourhood. Urban Research \& Practice, 11(2), 139-158.

Aitken, S. (2001). Geographies of young people: The morally contested spaces of identity. London: Routledge.

Alexander, S. A., Frohlich, K. L., \& Fusco, C. (2018). Play, physical activity and public health: The reframing of children's leisure lives. London: Routledge.

Altheide, D., Coyle, M., DeVriese, K., \& Schneider, C. (2008). Emergent qualitative document analysis. Handbook of emergent methods, 127-151

Amar, P. (2012). Global south to the rescue: emerging humanitarian superpowers and globalizing rescue industries. Globalizations, 9(1), 1-13.

Atkinson, M., \& Young, K. (2012). Shadowed by the corpse of war: Sport spectacles and the spirit of terrorism. International Review for the Sociology of Sport, 47(3), 286-306.

Bellas, L., \& Oliver, R. (2016). Rescaling ambitions: Waterfront governance and Toronto's 2015 Pan American Games. Journal of Urban Affairs, 38(5), 676-691.

Borden, I. (2003). Skateboarding, space and the city: Architecture and the body. London: Berg.

Boudreau, J. A., Keil, R., \& Young, D. (2009). Changing Toronto: Governing urban neoliberalism. Toronto: University of Toronto Press.

Boykoff, J. (2014). Activism and the Olympics: Dissent at the games in Vancouver and London. New Jersey: Rutgers University Press.

Boyle, P., \& Haggerty, K. D. (2009). Spectacular security: Mega-events and the security complex. International Political Sociology, 3(3), 257-274.

Broudehoux, A. M. (2017). Mega-events and urban image construction: Beijing and Rio de Janeiro. New York: Routledge.

Canadian Centre for Policy Alternatives. (2018). Child Welfare in a Neoliberal Era: Past, Present and Future. Available at https://www.policyalternatives.ca/sites/default/files/uploads/publications/Manitoba\%20 Office/2013/03/Child\%20welfare_0.pdf. Accessed 21 Nov 2018.

CBC News. (2013). No affordable housing on the waterfront, says Rob Ford. Available at: http://www.cbc. $\mathrm{ca} /$ news/canada/toronto/no-affordable-housing-on-the-waterfront-says-rob-ford-1.2287508. Accessed 30 June 2018.

Cornelissen, S. (2011). Mega event securitisation in a third world setting: glocal processes and ramifications during the 2010 FIFA World Cup. Urban Studies, 48(15), 3221-3240.

Cox, A. (2015). Shapeshifters: Black girls and the choreography of citizenship. Durham: Duke University Press.

Derrida, J. (1999). Adieu to Emmanuel Levinas. Stanford: Stanford University Press.

Derrida, J. (2006). The principle of hospitality. Parallax, 11(1), 6-9.

Desfor, G., \& Laidley, J. (Eds.). (2011). Reshaping Toronto's waterfront. Toronto: University of Toronto Press.

Dhillon, J. (2017). Prairie rising: Indigenous youth, decolonization, and the politics of intervention. Toronto: University of Toronto Press.

Dikeç, M., Clark, N., \& Barnett, C. (2009). Extending hospitality: giving space, taking time. Paragraph, $32(1), 1-14$.

Dillabough, J. A., \& Kennelly, J. (2010). Lost youth in the global city: Class, culture and the urban imaginary. New York: Routledge.

Dion, K. L. (2001). Immigrants' perceptions of housing discrimination in Toronto: the housing new Canadians project. Journal of Social Issues, 57(3), 523-539.

Doherty, A., \& Taylor, T. (2007). Sport and physical recreation in the settlement of immigrant youth. Leisure / Loisir, 31(1), 27-55. 
Du Toit, A. (2004). 'Social exclusion' discourse and chronic poverty: a South African case study. Development and Change, 35(5), 987-1010.

Falcous, M., \& Silk, M. L. (2010). Olympic bidding, multicultural nationalism, terror, and the epistemological violence of 'Making Britain Proud'. Studies in Ethnicity and Nationalism, 10(2), 167-186.

Farrugia, D. (2017). Space of youth: work, citizenship and culture in a global context. London: Routledge.

Fine, M., \& Ruglis, J. (2009). Circuits and consequences of dispossession: the racialized realignment of the public sphere for U.S. youth. Transforming Anthropology, 17(1), 20-33.

Fleming, S. (2016). Youth sport, race and ethnicity. In K. Green \& A. Smith (Eds.), Routledge handbook of youth sport (pp. 287-296). Oxon: Routledge.

Foley, E., Ross, L., \& Arista, C. (2013). Basketball courts, street corners and empty lots: The spatial dimensions of youth fear and vulnerability to violence. Children, Youth and Environments, 23(1), 43-63.

Foucault, M. (1977). Discipline and punish: The birth of the prison. London: Penguin.

Fusco, C. (2007). "Healthification" and the promises of urban space: a textual analysis of representations of place, activity, youth (PLAY-ing) in the city. International Review for the Sociology of Sport, 423(1), 43-63.

Fusco, C. (2008). Naked truths. Ethnographic dilemmas of doing research on the body in social spaces. In K. Gallagher (Ed.), The methodological dilemma: creative, critical and collaborative approaches to qualitative research (pp. 159-184). New York: Routledge.

Fusco, C. (2009). Subjection, surveillance, and the place(s) of performance: The discursive productions of space in Canada's national sport centre policy. Sport History Review, 40(1), 1-29.

Fusco, C. (2012). Governing PLAY: Moral geographies, healthification and neo-liberal urban imaginaries. In D. Andrews \& M. Silk (Eds.), Sport and neo-liberalism (pp. 143-159). Philadelphia: Temple University Press.

Fussey, P., \& Coaffee, J. (2017). Hollow sovereignty and the hollow crown? Contested governance and the olympic security edifice. In P. Cohen \& P. Watt (Eds.), London 2012 and the post-Olympics city (pp. 5387). London: Palgrave Macmillan.

Gaffney, C. T. (2010). Temples of the earthbound gods: Stadiums in the cultural landscapes of Rio de Janeiro and Buenos Aires. Austin: University of Texas Press.

Gallagher, K., \& Fusco, C. (2006). I.D.ology and the technologies of public (school) space: an ethnographic inquiry into the neo-liberal tactics of social (re)production. Journal of Ethnography and Education, 1(3), 301-318.

Geeraert, A., \& Gauthier, R. (2018). Out-of-control Olympics: Why the IOC is unable to ensure an environmentally sustainable Olympic Games. Journal of Environmental Policy \& Planning, 20(1), 16-30.

Geobey, S. (2013). The young and the jobless. Toronto: Canadian Centre for Policy Alternatives.

Giardina, M., \& Donnelly, M. (2007). Youth cultures and sport: Identity, power, and politics. New York: Routledge. Giroux, H. (2004). The terror of neoliberalism: Authoritarianism and the eclipse of democracy. Boulder: Paradigm.

Giulianotti, R., \& Klauser, F. (2010). Security governance and sport mega-events: toward an interdisciplinary research agenda. Journal of Sport \& Social Issues, 34(1), 49-61.

Goffman, E. (1956). The presentation of self in everyday life. Garden City, NY: Doubleday.

Goldberg, D. T. (1993). Racist culture: Philosophy and the politics of meaning. Cambridge: Blackwell.

Government of Canada. (2016). Understanding the Realities: Youth Employment in Canada: Interim report of the Expert Panel on Youth Employment. Available at https:/www.canada.ca/en/employment-socialdevelopment/corporate/youth-expert-panel/interim-report.html. Accessed 21 Nov 2018.

Government of Canada. (2018). Long term athlete development. Available at: https://www.canada. ca/en/canadian-heritage/services/developing-athletes.html\#a1. Accessed 5 June 2018.

Green, K., \& Smith, A. (2016). Routledge handbook of youth sport. Oxon: Routledge.

Grix, J., \& Houlihan, B. (2014). Sports mega-events as part of a nation's soft power strategy: the cases of Germany (2006) and the UK (2012). The British Journal of Politics and International Relations, 16(4), $572-596$.

Hartmann, D. (2016). Midnight basketball: Race, sports and neoliberal social policy. Chicago: Chicago University Press.

Harvey, D. (2008). The right to the city. New Left Review, 53, 23-40.

Holloway, S., \& Valentine, G. (2000). Children's geographies: Playing, living, learning. London: Routledge.

Hubbard, P., \& Wilkinson, E. (2014). Welcoming the world? Hospitality, homonationalism and the London 2012 Olympics. Antipode, 47, 598-615.

Hulchanski, J.D. (2010). The three cities within Toronto: Income polarization among Toronto's neighbourhoods, 1970-2005. Available at: http:/www.urbancentre.utoronto.ca/pdfs/curp/tnrn/ThreeCities-Within-Toronto-2010-Final.pdf. Accessed 8 May 2018.

Hume, C. (15 August 2014). East end Toronto a developer's dream. Toronto Star. Available at https://www. thestar.com/news/gta/2014/08/15/east_end_toronto_a_developers_dream_hume.html. Accessed 5 Dec 2018. 
Infrastructure Ontario. (2011). Construction underway for new West Don Lands Community in Time for 2015 Pan/Parapan American Games. Available at: http://www.infrastructureontario.ca/Financial-Close-PanAm-Athletes-Village/. Accessed 30 June 2018.

James, R. K. (2010). From 'slum clearance' to 'revitalisation': planning, expertise, and moral regulation in Toronto's Regent Park. Planning Perspectives, 25(1), 69-86.

Johnson, L., \& Johnson, R. (2017). Regent park redux: Reinventing public housing in Canada. New York: Routledge.

Kennelly, J. (2016). Olympic exclusions: Youth, poverty and social legacies. New York: Routledge.

Kennelly, J., \& Watt, P. (2011). Sanitizing public space in Olympic host cities: the spatial experiences of marginalized youth in 2010 Vancouver and 2012 London. Sociology, 45(5), 765-781.

Kennelly, J., \& Watt, P. (2013). Restricting the public in public space: the London 2012 Olympic Games, hyper-securitization and marginalized youth. Sociological Research Online, 18(2), 1-6.

Kidd, B. (2013). The global sporting legacy of the Olympic movement. Sport in Society, 16(4), 491-502.

King, R. (2007). Hostile environments: Anti-Indian imagery, racial pedagogies, and youth sports cultures. In M. Giardina \& M. Donnelly (Eds.), Youth cultures \& sport: Identity, power, and politics (pp. 147-160). New York: Routledge.

Kipfer, S. (2008). How Lefebvre urbanized Gramsci: Hegemony, everyday life, and difference. In K. Goonewardena, S. Kipfer, R. Milgrom, \& C. Schmid (Eds.), Space, difference, everyday life: Reading Henri Lefebvre (pp. 193-211). New York: Routledge.

Kipfer, S., \& Keil, R. (2002). Toronto Inc? Planning the competitive city in the new Toronto. Antipode, 34(2), 227-264.

Lefebvre, H. (1991). The production of space (trans. Nicholson-Smith, D., Vol. 142). Blackwell: Oxford.

Lenskyj, H. (2012). Best Olympics ever? The social impacts of Sydney 2000. Albany: SUNY Press.

Lipman, P. (2011). The new political economy of urban education: Neoliberalism, race and the right to the city. New York: Routledge.

Macdonald, D., Abbott, R., Knez, K., \& Nelson, A. (2009). Taking exercise: Cultural diversity and physically active lifestyles. Sport, Education and Society, 14(1), 1-19.

Maple Leaf Sports and Entertainment Foundation. (2015). New games court to benefit children and youth in Toronto's St. James Town community. Available at: http://www.mlsefoundation.org/News-Media/LatestNews/News-Items/New-games-court-to-benefit-children-and-youth-in-T.aspx. Accessed 24 Aug 2018.

Ministry of Municipal Affairs. (11 October 2012). Pan and Parapan Am Games to create affordable housing legacy. Available at: https://news.ontario.ca/mma/en/2012/10/pan-and-parapan-am-games-to-createaffordable-housing-legacy.html. Accessed 30 June 2018.

Monaghan, J. (2014). Security traps and discourses of radicalization: Examining surveillance practices targeting Muslims in Canada. Surveillance and Society, 12(4), 485-501.

Murdie, R. A. (2008). Pathways to housing: The experiences of sponsored refugees and refugee claimants in accessing permanent housing in Toronto. Journal of International Migration and Integration, 9(1), 81-101.

Nakamura, Y., \& Donnelly, P. (2017). Interculturalism and physical cultural diversity in the greater Toronto area. Social Inclusion, 5(2), 111-119.

Nitsch, V., \& Wendland, N. (2017). The IOC's midas touch: summer Olympics and city growth. Urban Studies, 54(4), 971-983.

O'Bonsawin, C. M. (2010). 'No Olympics on stolen native land': contesting Olympic narratives and asserting indigenous rights within the discourse of the 2010 Vancouver games. Sport in Society, 13(1), 143-156.

Oliver, R. (2017). Sport mega event planning in Toronto: from a democratic demand to a democratic demise. The Canadian Geographer / Le Géographe Canadien, 61(2), 292-299.

Philo, C., \& Smith, F. (2003). Guest editorial: political geographies of children and young people. Space and Polity, 7, 99-115.

Potwarka, L., \& Leatherdale, S. (2016). The Vancouver 2010 Olympics and leisure-time physical activity rates among youth in Canada: any evidence of a trickle-down effect? Leisure Studies, 35(2), 241-257.

Prouse, C. (2013). Framing the World cUPP: Competing discourses of favela pacification as a mega-event legacy in Brazil. Recreation and Society in Africa, Asia and Latin America, 3(2), 4-20.

Puwar, N. (2004). Space invaders. Oxford, UK: Berg.

Raco, M. (2014). Delivering flagship projects in an era of regulatory capitalism: State-led privatization and the London Olympics 2012. International Research of Urban and Regional Research, 38(1), 176-197.

Razack, S. (2002). Race, space and the law: Unmapping a white settler society. Toronto: Between the Lines Press.

Richmond, M. A., \& Garmany, J. (2016). 'Post-third-world city' or neoliberal 'city of exception'? Rio de Janeiro in the Olympic era. International Journal of Urban and Regional Research, 40(3), 621-639. 
Rodericks, D., Gallagher, K., Haag, J., Wortley, S., Fusco, C., De Lisio, A., DiCarlo, D., and McCready, L. (2018). Crossing places: A review of urban youth policy 1960s-2010s. Research Paper 243. Cities Centre (Neighbourhood Change Research Partnership), University of Toronto. ISSN 0316-0068.

Ruddick, S. (2014). Constructing differences in public spaces: Race, class, and gender as interlocking systems. In J. Gieseking \& W. Mangold (Eds.), The people, place and space reader (pp. 7-11). New York: Routledge.

Saberi, P. (2017). Toronto and the 'Paris problem': Community policing in 'immigrant neighbourhoods'. Race \& Class, 59(2), 49-69.

Schimmel, K. S. (2012a). Protecting the NFL/militarizing the homeland: Citizen soldiers and urban resilience in post-9/11 America. International Review for the Sociology of Sport, 47(3), 338-357.

Schimmel, K. (2012b). Neoliberal redevelopment, sport infrastructure, and the militarization of U.S. urban terrain. In M. Silk \& D. Andrews (Eds.), Sport and neoliberalism (pp. 160-176). Philadelphia: Temple University Press.

Silk, M. (2014). The London 2012 Olympics: The cultural politics of urban regeneration. Journal of Urban Cultural Studies, 1(2), 273-293.

Silk, M. L. (2018). Sporting spectacle, 9/11 and the reconstitution of the American nation. In D. Paddy \& J. Connolly (Eds.), Sport and national identities: Globalization and conflict. New York: Routledge.

Silk, M., \& Andrews, D. (2012a). Sport and the neoliberal conjecture: Complicating consensus. In M. Silk \& D. Andrews (Eds.), Sport and neoliberalism (pp. 1-19). Philadelphia: Temple University Press.

Silk, M., \& Andrews, D. (2012b). The governance of the neoliberal sporting city. In M. Silk \& D. Andrews (Eds.), Sport and neoliberalism (pp. 127-142). Philadelphia: Temple University Press.

Silk, M., \& Manley, A. (2017). Urban and securitized spaces. In M. Silk, D. Andrews, \& H. Thorpe (Eds.), Routledge handbook of physical cultural studies (pp. 344-354). New York: Routledge.

Sirin, S., \& Fine, M. (2007). Hyphenated selves: Muslim American youth negotiating identities on the fault lines of global conflict. Applied Developmental Science, 11(3), 151-163.

Social Planning Council of Ottawa (2018). Youth Employment, Unemployment and Under-Employment in Ottawa. Available at https://www.spcottawa.on.ca/sites/all/files/Youth\%20Employment\%20-\%20 May\%2029\%202014.pdf. Accessed 21 Nov 2018.

Social Planning Toronto. (2016). Newcomer Youth Access to Recreation in Toronto: Relationships, resources and relevance. Available at http://www.socialplanningtoronto.org/wp-content/uploads/2016/03 /Newcomer-Youth-Recreation-FINAL.pdf. Accessed 11 June 2018.

Statistics Canada. (2011). Census tract profile for 0065.00, Toronto, Ontario. Ottawa: Statistics Canada Catalogue.

Steinbrink, M. (2014). Festifavelisation: Mega-events, slums and strategic city-staging - the example of Rio de Janeiro. DIE ERDE: Journal of the Geographical Society of Berlin, 144(2), 129-145.

Taylor, T., \& Doherty, A. (2005). Adolescent, sport, recreation and physical education: Experiences of recent arrivals to Canada. Sport, Education and Society, 10(2), 211-238.

TO2015. (2009). 2015 Pan/Parapan American Games Bid Book. Available at: http://www.gamesbids. net/library/applicant files/2015/Toronto2015BB.pdf. Accessed 8 May 2018.

TO2015. (2013). Towards Toronto 2015: Diversity and inclusion progress report. Available at: http://images. toronto2015.org/system/asset_pdfs/2897/original/diversity-inclusion-report2013.pdf. Accessed 30 June 2018.

Valentine, G. (1996). Angels and devils: Moral landscapes of childhood. Environment and Planning D: Society and Space, 14, 581-599.

Vanwynsberghe, R. (2015). The Olympic Games Impact (OGI) study for the 2010 Winter Olympic Games: strategies for evaluating sport mega-events' contribution to sustainability. International Journal of Sport Policy and Politics, 7(1), 1-18.

Vanwynsberghe, R., Surborg, B., \& Wyly, E. (2013). When the games come to town: Neoliberalism, megaevents and social inclusion in the Vancouver 2010 winter Olympic Games. International Journal of Urban and Regional Research, 37(6), 2074-2093.

Veal, A., Toohey, K., \& Frawley, S. (2012). The sport participation legacy of the Sydney 2000 Olympic Games and other international sporting events hosted in Australia. Journal of Policy Research in Tourism, Leisure and Events, 4(2), 155-184.

Waterfront Toronto (2011). Toronto 2015 Pan/Parapan American Games Athletes' Village. Available at: www. waterfrontoronto.ca/explore_projects $2 /$ west_don_lands/2015_pan_american_games. Accessed 8 May 2018.

Watt, P. (2008). The only class in town? Gentrification and the middle-class colonization of the city and the urban imagination. International Journal of Urban and Regional Research, 32(1), 206-211.

Watt, P. (2013). 'It's not for us': Regeneration, the 2012 Olympics and the gentrification of East London. City, 17(1), 99-118. 
Wortley, S., \& Owusu-Bempah, A. (2014). The usual suspects: Police stop and search practices in Canada. Policing and Society, 21(4), 395-407.

Wright, J., \& Macdonald, D. (2010). Young people, physical activity and the everyday. London: Routledge.

Youth Unemployment, Research Project. (2016). Tired of the hustle: Youth voices on employment. Available at http://accessalliance.ca/wp-content/uploads/2017/01/TiredoftheHustleReport.pdf. Accessed 21 Nov 2018.

Zaami, M. (2015). "I fit the description": Experiences of social and spatial exclusion among Ghanaian immigrant youth in the Jane and Finch neighbourhood of Toronto. Canadian Ethnic Studies, 47(3), 69-89.

Zuberi, D., \& Taylor, A. (2017). Securing the urban core: Policing poverty and migration in the neoliberal city. In P. Bourbeau (Ed.), Handbook on migration and security (pp. 144-160). Cheltenham: Edward Elgar Publishing Inc. 